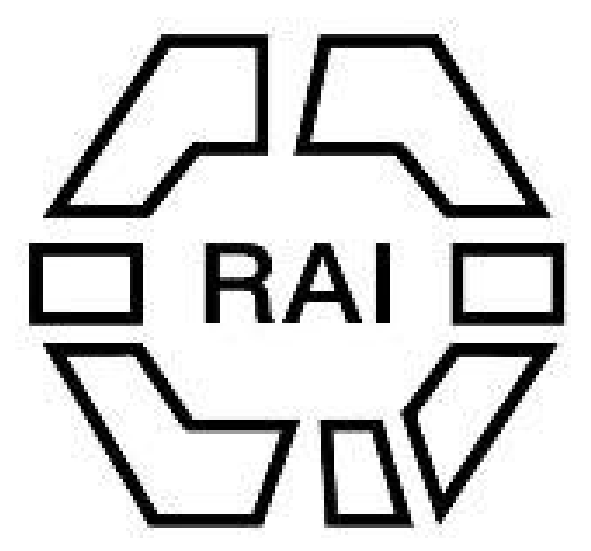

\title{
WILEY
}

\section{An Akikuyu Image.}

Authors(s): W. Scoresby Routledge

Source: Man, Vol. 6 (1906), pp. 1-3

Published by: Royal Anthropological Institute of Great Britain and Ireland

Stable URL: http://www.jstor.org/stable/2788062

Accessed: 27-03-2016 04:18 UTC

\section{Your use of the JSTOR archive indicates your acceptance of the Terms \& Conditions of Use, available at}

http://about.jstor.org/terms

JSTOR is a not-for-profit service that helps scholars, researchers, and students discover, use, and build upon a wide range of content in a trusted digital archive. We use information technology and tools to increase productivity and facilitate new forms of scholarship. For more information about JSTOR, please contact support@jstor.org.

Royal Anthropological Institute of Great Britain and Ireland, Wiley are collaborating with JSTOR to digitize, preserve and extend access to Man

http://www.jstor.org 

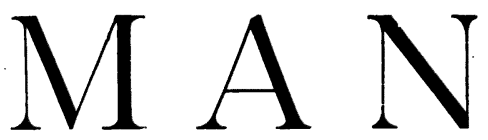

\section{A MONTHLY RECORD OF ANTHROPOLOGICAL SCIENCE.}

\section{PUBLISHED UNDER THE DIRECTION OF}

THE ANTHROPOLOGICAL INSTITUTE OF GREAT BRITAIN AND IRELAND.

N.B.-All communications printed in MaN are signed or initialled by their authors, and the Council of the Institute desires it to be understood that in giving publicity to them it accepts no responsibility for the opinions or statements expressed.

N.B.-MAN, 1906, consists of twelve monthly-published sheets, of sixtecn pages cuch, printed in single column; containing "Original Articles" and substantial. "Revicws" of recent publications; all numbered consecutively 1, 2, 3, onvards.

N.B. - Articles published in MAs should be quoted by the ycar, and the reforence-number of the article, not by the page-reference; e.g., the urticle which begins on p. 3 below should be quoted us MaN, 1906. 2.

\section{ORIGINAL ARTICLES.}

Africa : East.

With Plate A.

Routledge.

An Akikuyu Image. By $W$. Scorcsby Routlculge, M.A.

The image that forms the froutispiece of the present number of MaN bas been obtained for the British Museum by Mrs. Sidney L. Hinde, the wife of H.M. Sub-Commissioner for the Kenia province. I have been asked to write a few notes about it in her absence.

In 1903 I was living in the country of the Akikuyu, in the district of the petty chieftain Wombugu, whose village is situated on the River Goura, midway between the points now indicated on the map as Fort Hall and Fort Nyeri, in the province of Kenia in British East Africa.

Coming one day suddenly over the sky-line of what proved to be a sort of huge natural amphitheatre, I saw at the bottom a large number, perbaps $5(00$, of people--say 300 men and the rest women and children. The women and children, dressed in the usual way, stood around as spectators, availing themselves of the natural rise of the ground the better to see, but they took no active part whatsoever in the ceremony.

The men were specially dressed for the occasion and formed up as a compact body in the arena.

The elements of the men's dress were the same as in everyday life plus the special shoulder wings or shields invariably employed in dancing, but the material of their dress was exclusively the dry, whitish-yellow, fibrous sheath that forms the outer covering of a cob of ripe maize instead of being the fur of the Colobus monkey, as is customary.

The costume consisted of :-

(1.) A garland formed by a hoop, to which was attached about thirty maze sheaths standing out from the head like the rays of a star.

(2.) A shoulder wing or frame projecting upwards above the head about 9 inches, and consisting of an armlet passing round the arm as high up as possible, from which sprang a light cane ovoid hoop with its circumference directed forwards and backwards, to the periphery of which was attached tufts of the dry maze sheaths.

By constant informal practice a Kikuyu can impart from the muscles of the shoulder a peculiar quivering movement to these shoulder dancing shields that much 


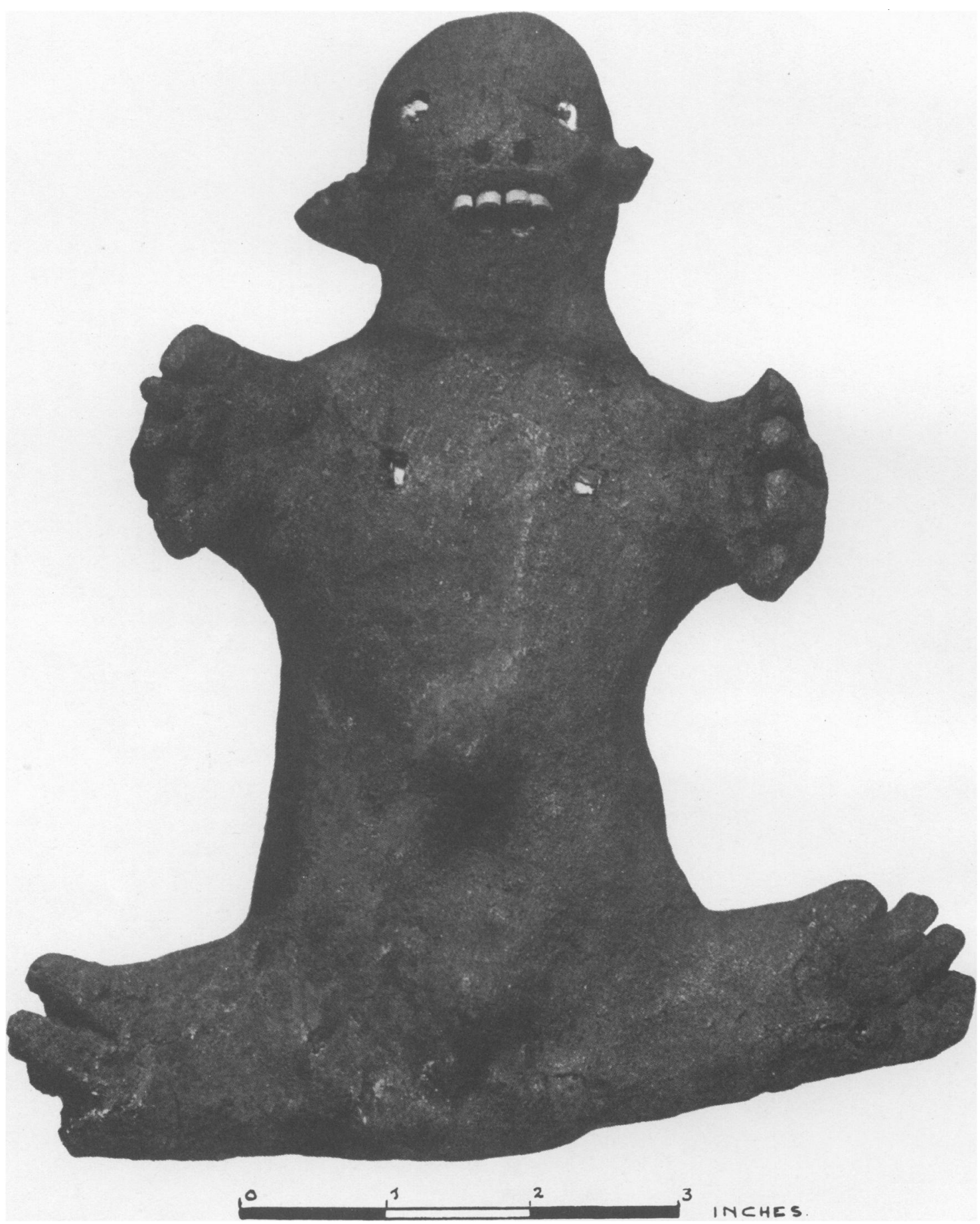

CLAY CEREMONIAL FIGURE FROM KIKUYU. 
resembles the action of the wings of a young bird when anticipating food from the parent, and the effect of such, in the case of a large number of dancers, is most effective.

(3.) An armlet worn just above the elbow, from which depended a bunch of maze sheath-the equivalent of the white bushy tail of the Colobus monkey (Guu) usually worn at the dance.

(4.) A circlet placed just above the curve of the calf of the leg formed of cane, of which the ends, extending about six inches backwards, allowed the maze sheaths to be arranged like the long white back-hair of the Colobus.

In their hands they carried, instead of the usual life preserver (jo-rō-ma), a stick about two feet long, to the extremity of which a large tuft of maize sheath was attached.

A small group of elders stood facing the crowd, and one of their number addressed it. The assembled performers then went through certain complicated Sir Roger de Coverley-like movements in a series of short jumping steps, and finally ranged up in front of the elders. (This particular jumping step is practised at odd times.)

One of the old men then very carefully unwrapped the sundried clay image from its covering of green banana leaves, and, supporting it on his extended palms, held at the level of his face, proceeded to dance it up and down.

Immediately on his so doing the crowd secmed to go wild with excitement, apparently applauding and at the same time going through the set steps in perfect time, but more vigorously than ever, and without moving from the spot where each man stood.

The image was then elevated for adoration three or four times and then carefully wrapped up and put away.

The whole party departed to go through the same ceremony elsewhere, so they told me. The proceedings took about half-an-hour.

Some time previously when talking with the Akikuyu, I had made very precise enquiries as to what constituted good looks in a man and a woman; and it was then impressed upon me by them that perfect beauty required a low forehead, a long neck, and a pronounced umbilicus (slight umbilical hernia). I was much struck, therefore, by the way in which the figure conformed to the canons of beauty thus previously laid down.

The Akikuyu always referred to the figure as "the little one," and explained to me that whosoever saw it must needs dance-he danced involuntarily.

These images are sometimes male and sometimes female. The one I first saw and subsequently acquired was a female, the sex being indicated by the small triangular apron which custom amongst the Akikuyu requires even the youngest female child always to wear, but the breasts were quite unindicated beyond being marked by a couple of blue beads. It seemed to me at the time that the figure was not intended specially to express the idea of femininity or motherhood, a view that was proved afterwards to be correct by similar male figures being brought to me.

Being well known to everybody present, either personally or by repute, I had no difficulty in being allowed to be present or even in taking photographs, but, though I expressed the greatest interest and devotion and made handsome presents to the image, it was somehow so arranged that in the two whole years amongst them $I$ never saw the ceremony again repeated.

My friends explained to me that there was nothing sacred in the image itself, but that no one would think of treating it with disrespect, and that it was kept buried in the store of pounded maize flour to protect it from injury. 
This festival takes place immediately after the in-gathering of the crops, i.e., biennially.

It is a rather remarkable fact that two Government punitive expeditions raided this district subsequently but never found one of these images, for, had one been found, it would certainly have been brought in by the black troops, who quite know the value of curios.

SCORESBY ROUTLEDGE.

Egypt: Craniology.

Keith.

Were the Ancient Egyptians a Dual Race? By Arthur Keith, M.D.

My review of The Ancient Races of he Thebaïd* has been criticised by 2 Professor Arthur Thomson† and Professor Karl Pearson. $\neq$ A closer reading and more intimate acquaintance with biometrical methods compel me to admit the justice of Professor Pearson's criticism; I certainly placed undue importance on the preliminary essay made by Miss Fawcett to test the homogeneity of the Naqada crania from an examination of their length aud breadth measurements. But the main problem discussed in my review was the interpretation of certain characters of Egyptian crania, which, because they are present in the skulls of negroes, may be conveniently styled negroid. Miss Fawcett $\$$ noted a number of these, amongst which were the height and breadth of the upper face, the upper face index, the height of the nose, and the cephalic index. The presence of these characters did not effect the homogeneity of the ancient Egyptian as a race when tested by biometrical methods and compared with other races which are usually regarded as pure. The authors of The Ancient Races of the Thebaïd also noted these negroid characters, especially the upper face and nasal measurements, and, to explain their presence in one type of skull and their absence in another, formulated the theory that there were two races in ancient Egypt-a negroid and a non-negroid. When I wrote my review I had in mind the description which Sir Harry Johnston\| has given of the tribes in the Uganda protectorate, especially of the Bahima in which the negro and hamite characters are blended in varying degrees; it appeared to me that a more probable explanation of the negroid characters found in the crunia of ancient Egyptians was to suppose that there had been a direct infusion of negro blood in the Egyptian stock. It may be, however, that the ancient Egyptians and negroes obtaiued these characters from a common stock or even independently. The main point at issue is this : were the ancient Egyptians a single or a dual race? Two methods are available for the solution of this question : the biometrical method, or the method of anatomical analysis ; Professor Pearson uses the one, Professor Thomson the other. It seems to me a perfectly legitimate proceeding to test these methods on a collection of measurements drawn from two distinct races to see how far, or with what degree of accuracy, the mixture may be detected. I especially wished to see if they would detect an artificial addition of negro measurements to those of ancient Egyptians. The measurements used were those given by Thomson and MacIver for the male crania of ancient Egyptians, and those given by Shrubsall for modern male negroes. Because of the labour entailed I only used six measurements; these are given in the accompanying table. I take this opportunity of expressing my indebtedness to Mr. P. I. Wutkin, Lecturer on Physics at St. Thomas's Hospital Medical School, who worked out the table for me. The data represents a mixture of about one-eightb negro with seveneighths ancient Egyptian. The negro infusion may be regarded as such a proportion as is represented by a race that successfully invades and conquers another. I propose to apply first what may be called the biometrical method, and then what may be named for convenience the Oxford method of analysis.

* Max, June, 1905, No. 55.

$\ddagger$ MAN, August, 1905, No. 65.
+ MaN, July, 1905, No. 58.

§ Biometrika, Vol. I., p. 436.

II The Uganda Protectorate, Vol. II., p. 485, et seq.

$\left[\begin{array}{ll}3 & ]\end{array}\right.$ 